\title{
KILKA UWAG \\ O PARAMEDYCZNYM ZASTOSOWANIU OLIWY PRZEZ CHRZEŚCIJAN W OKRESIE WCZESNOBIZANTYŃSKIM**
}

W relacjach wczesnobizantyńskich autorów chrześcijańskich oraz w ówczesnych kościelnych tekstach normatywnych natrafiamy na opisy praktyk leczniczych z wykorzystaniem oliwy ('̌ $\lambda \alpha \iota$ v). Jej zastosowanie w dolegliwościach dermatologicznych lub gastrycznych było wówczas postrzegane jako skuteczny, a nierzadko również jedyny dostępny zabieg leczniczy ${ }^{1}$. W zestanych poniżej relacjach nie mamy jednak do czynienia ze zwykłą praktyką medyczną. Obrazują one bowiem przypadki wykorzystania w celach leczniczych

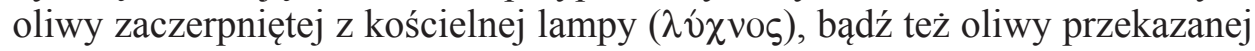
w tym celu przez duchownych, którzy wcześniej odmówili nad nią modlitwę. Tak pozyskanej oliwie przypisywano szczególną skuteczność. Z tego też względu możemy mówić, iż opisane poniżej przypadki to praktyki bardziej o charakterze paramedycznym (żeby nie powiedzieć - magicznym), niż tylko leczniczym. W starożytności, w przypadku wielu zabiegów leczniczych, granica między medycyną a magią była dość cienka². Zasadność tak brzmiącego stwierdzenia potwierdzają także opisane poniżej przypadki, charakteryzujące

* Dr hab. Ireneusz Milewski, prof. UG - profesor nadzwyczajny w Zakładzie Historii Starożytnej w Instytucie Historii na Wydziale Historycznym Uniwersytetu Gdańskiego; e-mail: hisim@ univ. gda.pl.

${ }^{* *}$ Artykuł został napisany w związku z realizacją grantu finansowanego przez Narodowe Centrum Nauki: UMO-2011/01/B/HS3/01233.

${ }^{1}$ Por. K. Pollak, Die Heilkunde der Antike, Wiesbaden 1969, 256.

${ }^{2}$ Por. L. Edelstein, Greek Medicine in its Relation to Religion and Magic, w: Ancient Medicine, Baltimore 1967, 217-246; D.W. Amundsen, Medicine and Faith in Early Christianity, „Bulletin of the History of Medicine" 56 (1982) 326-350; tenże, Medicine, Society, and Faith in the Ancient and Medieval World, Baltimore 1996, 127-157; V. Nutton, From Galen to Alexander. Aspects of Medicine and Medical Praectice in Late Antiquity, DOP 38 (1984) 1-14; G..B. Ferngren, The Early Christian Reception of Greek Medicine, w: Beyond „Reception”. Mutual Influences between Antique Religion, Judaism, and Early Christianity, hrsg. D. Brakke - A.Ch. Jacobsen - J. Ulrich, Frankfurt am Main 2006, 155-173; D. Montserrat, ,Carrying on the Work of the Earlier Firm”: Doctors, Medicine and Christianity in the Thaumata of Sophronius of Jerusalem, w: Health in Antiquity, ed. H. King, London - New York 2005, 230-242. 
się przypisywaniem szczególnych właściwości leczniczych oliwie pozyskanej w kościele lub w martyrionie. Przeanalizujmy wybrane relacje.

1. Relacje wczesnobizantyńskich autorów chrześcijańskich. Najstarsze relacje dotyczące interesujących mnie tu praktyk wyszły spod pióra Jana Chryzostoma w okresie antiocheńskim. W pierwszej z Chryzostomowych relacji czytamy:

„Wszak kościół jest wspólnym domem wszystkich, a my wchodzimy dopiero, gdy już wy go wcześniej zajmiecie, zachowując przykład tamtych. Dlatego przekazujemy wszystkim pokój zaraz przy wejściu, stosownie do owego przykazania (por. Mt 10,12). Niechaj nikt nie będzie nieuważny, nikt roztargniony, gdy wchodzą kapłani i nauczyciele; wyznaczono za to niemałą karę. Bo przynajmniej ja tysiąc razy wolałbym doznać zniewagi, wszedłszy do domu któregoś z was, niż żeby mnie nie słuchano, gdy tu przemawiam. Jest to dla mnie cięższe niż tamto, bo i ten dom jest znakomitszy. Tutaj są bowiem złożone nasze wielkie skarby; tu są nasze wszystkie nadzieje. Czyż znajduje się tu coś takiego, co nie byłoby wielkie i nie przejmowałoby drżeniem? Stół ten jest o wiele słodszy i bardziej zaszczytny, a i lampa jest lepsza od twojej. Wiedzą o tym ci, którzy w odpowiednim czasie z wiarą namaścili się oliwą z niej i uwolnili się od chorób"3.

Chryzostom odnosi się do wspomnianej przez siebie praktyki z uznaniem i wyraźnie akcentuje, że o skuteczności zastosowanej oliwy decyduje fakt, iż została ona zaczerpnięta z kościelnej lampy ( $\lambda$ ó $v o \varsigma)$. Przede wszystkim jednak wskazuje na świętość miejsca, w którym oliwę tę pozyskano. Nie mniej istotny jest $\mathrm{w}$ tym przypadku również kolejny czynnik warunkujący skuteczność zastosowanej praktyki (akcentowany także w relacjach innych autorów wczesnobizantyńskich), a mianowicie wiara, i to raczej w Chrystusa, a nie w skuteczność zabiegu ${ }^{4}$. Brak również doprecyzowania owego „odpowiedniego czasu", w którym cudowna oliwa powinna być zastosowana. Musiało się to zapewne zbiegać z którymś ze świąt, nie wykluczone, że ze świętem Zmartwychwstania.

Trudno natomiast stwierdzić, czy do interesującej nas tu kwestii nawiązuje Chryzostom w kolejnym ze swoich pism z okresu antiocheńskiego, a miano-

\footnotetext{
${ }^{3}$ Por. Joannes Chrysostomus, In Matthaeum hom. 32, 6, PG 57, 384, tłum. J. Krystyniacki, ŹMT 18, Kraków 1998, 382-383. W tej kwestii zob. także Ch. Markschies, Der Heilige Johannes Chrysostomus und die „Halbchristen”. Vortrag anlässlich der Verleihung der Ehrendoktorwürde, „Revista Teologica” 17 (2007) nr 2, 255; Th. Pratsch, ,...erwachte und war geheilt”. Inkubationsdarstellungen in byzantinischen Heiligenviten, ZACh 17 (2013) 83-84.

${ }^{4}$ Por. J. Kern, Ein missverstandenes Zeugnis des hl. Johannes Chrysostomus für das Sakrament der letzten Ölung, ZKTh 29 (1905) 382-389. Zob. także F. Fichtner, Christus als Arzt. Ursprünge und Wirkung eines Motivs, „Frühmitelalterliche Studien” 16 (1982) 1-18; P.D.E. Knipp, ,,Christus medicus" in der frühchristlcihen Sarkophagskulptur. Ikonographische Studien der Sepulkralkunst des späten vierten Jahrhunderts, Leiden 1998, 34-39.
} 
wicie w Dialogu o kapłaństwie. Jan pisząc o powadze stanu kapłańskiego oraz posiadanej przez duchownych „mocy usuwania nieczystości z duszy”, cytuje słowa zaczerpnięte z Listu św. Jakuba $(5,14-15)$ :

„Choruje ktoś wśród was? Niech weźmie kapłanów Kościoła, by się modlili nad nim i namaścili go olejem w imię Pana; modlitwa pełna wiary będzie dla chorego ratunkiem i podźwignie go Pan, a gdyby popełnił grzechy, będą mu odpuszczone (Jk 5, 14-15)"'5.

Przytoczony w Dialogu cytat z Listu św. Jakuba ma według Jana potwierdzać, iż opisana czynność wykonywana przez kapłanów służy odpuszczaniu grzechów. Tak też przekaz ten interpretuje Chrysostom Baur nie wdając się w żadne dywagacje na jego temat ${ }^{6}$. Natomiast Craig S. Keener w swym Komentarzu historyczno - kulturowym do Nowego Testamentu postrzega opisaną w Liście św. Jakuba praktykę jako medyczną?

Stosowanie interesujących nas tu praktyk z wykorzystaniem oliwy na terenie Syrii potwierdzają również inne relacje źródłowe. Wspomina o nich anonimowy autor Żywota Barsaumy. Według niego, oliwa pobłogosławiona przez mnicha Barsaumę nie tylko uśmierzała pewne dolegliwości, lecz działała także profilaktycznie, czyniąc namaszczonego nią człowieka niedostępnym dla chorób $^{8}$. O interesującej nas tu praktyce wspomina również Teodoret z Cyru w swej Historia religiosa, opisując cuda syryjskiego mnicha Symeona ${ }^{9}$. Więcej informacji odnajdujemy natomiast w Żywocie Daniela Stylity. Jak zapewnia nas jego autor, Daniel nierzadko osobiście nacierał chorych oliwą, innym razem zaś tylko ją przekazywał do indywidualnego zastosowania, zawsze jednak odmawiając nad nią modlitwę. Tym zaś, którzy poddawali się zabiegowi tłumaczył, iż to nie oliwa, lecz wiara w Boga okazywana przez chorego, może przynieść uzdrowienie. Autor Żywota wśród uzdrowionych w taki sposób wymienia paralityków, chromych, niemych, a nawet opętanych ${ }^{10}$.

${ }^{5}$ Joannes Chrysostomus, De sacerdotio III 6, ed. A.M. Malingrey, SCh 272, Paris 1980, 154, thum. W. Kania: Św. Jan Chryzostom, Dialog o kapłaństwie, BOK 1, Kraków 1992, 76.

${ }^{6}$ Por. Ch. Baur, Der heilige Johannes Chrysostomus und seine Zeit, Bd. 1: Antiochien, München 1929, 302.

${ }^{7}$ Por. C.S. Keener, Komentarz historyczno-kulturowy do Nowego Testamentu, red. nauk. wyd. pol. K. Bardski - W. Chrostowski, tłum. Z. Kościuk, Warszawa 200, 545. Podobnie utrzymuje również M.C. Albi, ,Are Any Among You Sick?”. The Health Care System in the Letter of James, JBL 121 (2002) 123-143.

${ }^{8}$ Por. F. Nau, Résumé de monographies syriaques, ROC 19 (1914) 114 i 281.

${ }^{9}$ Por. Theodoretus, Historia religiosa 26, 20, ed. P. Canivet - A. Leroy-Molinghen, SCh 257, Paris 1979, 200-202; thum K. Augustyniak: Teodoret z Cyru, Dzieje miłości Bożej, ŹM 7, Kraków - Tyniec 1994, 278.

${ }^{10}$ Por. Vita Sancti Danielis Stylitae 29, ed. H. Delehaye, w: tenże, Les saints stylites, Subsidia Hagiographica 14, Bruxelles - Paris 1923, 29; tamże 33, ed. Delehaye, s. 32; tamże 59, ed. Delehaye, s. 58; tamże 86, ed. Delehaye, s. 81; tamże 89, ed. Delehaye, s. 83. W tej kwestii zob. także H.J. Frings, Medizin und Arzt bei den griechischen Kirchenväter bis Chrysostomus, Bonn 1959, 25; R. le Coz, Les Pères de l'Église grecque et la médecine, BLE 98 (1997) 141-142; M. Dörnemann, 
Analogiczne relacje pochodzą także z innych prowincji Cesarstwa Wschodniorzymskiego. Przykład z Palestyny potwierdza, iż nie tylko w kościele, ale również u grobów męczenników czyniono interesujące nas praktyki. Według relacji Cyryla ze Scytopolis, przy grobie mnicha Eutychiusza wisiała wieczna lampa ( $\alpha \sigma \beta \varepsilon \sigma \tau o \varsigma \kappa \alpha \nu \delta \hat{\eta} \lambda \alpha)$, z której czerpano oliwę, by nacierać nią chorych $^{11}$. Oliwa zyskiwała szczególną moc po uprzednim rozlaniu jej na płytę grobu męczennika. Zebraną następnie oliwę przy pomocy tkaniny, wykorzystywano w praktykach leczniczych ${ }^{12}$.

Opisywany powyżej zwyczaj znany był także w Bitynii. O nacieraniu cho-

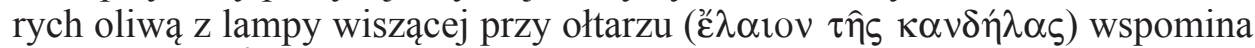
Kallinikos w Żywocie Hypatiosa. Z relacji tej wynika, iż święty mąż najczęściej sam nacierał chorych oliwą, czasami pozwalając na wykonywanie tej czynności jednemu z prezbiterów ${ }^{13}$.

Interesująca nas praktyka znana była także Cyrylowi Aleksandryjskiemu. Patriarcha stwierdza jednak, iż nie tyle nacieranie oliwą, co towarzysząca tej czynności modlitwa przyczynia się do powrotu do zdrowia ${ }^{14}$.

2. Praktyka leczniczego stosowania oliwy przez chrześcijan w kościelnych tekstach normatywnych epoki. Gdybyśmy w opisanych powyżej przypadkach mieli do czynienia z zastosowaniem w celach leczniczych zwykłej oliwy spożywczej, fakt ten raczej nie zostałby odnotowany w ówczesnych kościelnych tekstach normatywnych. Tymczasem praktyki te są definiowane konkretnymi regulacjami. Czytamy o nich między innymi w syryjskich aktach Soboru Nicejskiego. W kanonie 35. tego zbioru zapisano, iż duchowni błogosławią wodę i oliwę dla swych wiernych, w kolejnym zaś 64 . kanonie, czytamy o przyprowadzaniu chorych bądź opętanych do kościoła, gdzie otrzymują oni oliwę, uprzednio rozlaną na płytę nagrobną świętego

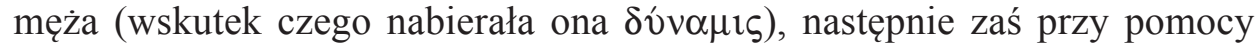
tkaniny zebraną do naczynka (a więc w analogiczny sposób, jak to opisuje Cyryl ze Scytopolis). Przekazywaniu oliwy przez duchownych towarzyszyło odmawianie modlitwy ${ }^{15}$.

Einer ist Arzt, Christus. Medizinales Verständnis von Erlösung in der Theologie der griechischen Kirchenväter des zweiten bis vierten Jahrhunderts, ZACh 17 (2013) 120.

${ }^{11}$ Por. Cyrillus Scythopolitanus, Vita Euthymi 52, ed. E. Schwartz, w: Kyrillos von Scythopolis, Vitae monachorum Palestinensium, TU 49/2, Leipzig 1939, 76, thum. E. Dąbrowska, w: Cyryl ze Scytopolis, Żywoty mnichów palestyńskich, ŹM 60, Kraków - Tyniec 2011, 234; tamże 54, ed. Schwartz, s. 76, ŹMT 60, 235.

${ }^{12}$ Por. B. Kötting, Devotionalien, RACh III 867.

${ }^{13}$ Por. Callinicus, Vita Hypatii 9, 6, ed. G.J.M. Bartelink, SCh 177, Paris 1971, 106; tamże 12, 10, SCh 177, 118; tamże 15, 1, SCh 177, 124; tamże 22, 13, SCh 177, 142; tamże 4, 7, SCh 177, 86.

${ }^{14}$ Por. Cyrillus Alexandrinus, De adoratione in spiritu et veritate 6, PG 68, 472A.

${ }^{15}$ Por. O. Braun, De sancta Nicaena synodo. Syrische Texte des Maruta von Maipherkat nach einer Handschrift der Propaganda zu Rom, Münster 1898, 84 (kan. 35) i 103 (kan. 64). W tej kwestii por. także F.J. Dölger, Beiträge zur Geschichte des Kreuzzeichens VII, JbACh 7 (1964) 9. 
Więcej informacji w odniesieniu do interesującej nas kwestii odnajdujemy w kościelnych tekstach normatywnych powstałych w kręgu egipskim. W arabskiej wersji Kanonów Hipolita czytamy:

„Jeśli idzie o chorych, to pójście do kościoła i otrzymanie wody modlitwy i oleju modlitwy jest dla nich lekarstwem, chyba że choroba jest poważna i osoba bliska śmierci. Wtedy kler niech odwiedza codziennie tych, którzy go znają"16.

Zgoła inaczej kwestię tę postrzegał autor Kanonów Bazylego. W kanonie 34. tego zbioru czytamy:

„Dlaczego potrzebuje on [tj. chrześcijanin - I.M.] chodzić do astrologa, czarownika, maga, wieszcza? Mamy przecież święty katolicki Kościół. Dlaczego mamy potrzebę bycia nacieranymi pełną nieczystości oliwą, skoro już wcześniej zostaliśmy namaszczeni olejami? Dlaczego potrzebujemy splamić się oliwą, która jest pełna brudu, by w taki sposób otworzyć nasze serca dla szatana?"17.

Ale już w dalszej części tego samego kanonu czytamy:

„[...] ten, który zachoruje, powinien wezwać z kościoła prezbiterów, którzy odmówią nad nim modlitwę i namaszczą go olejami wiary, tak aby chory został uleczony"18.

W kolejnym zaś kanonie 35. odnajdujemy szczegółowy opis takich praktyk leczniczych uprawianych po konsultacji z wróżbitą:

„Kiedy chrześcijanin udaje się do szarlatana po poradę, na zadane pytanie słyszy: poczekaj aż wstanie słońce, a wtedy zrób to lub tamto. Albo: poczekaj aż pojawi się księżyc. Albo: kiedy będzie pełnia księżyca, wykąp w wodzie chorego. Albo: kiedy zajdzie słońce, nasmaruj oliwą to lub tamto miejsce"19.

Cytowane powyżej fragmenty Kanonów Bazylego są jedynymi znanymi mi relacjami chrześcijańskimi, które wskazują na pogańską proweniencję interesującej nas tu praktyki. Przekonanie o szczególnej skuteczności oliwy poddanej magicznemu rytuałowi funkcjonowało u ludów starożytnych co najmniej od okresu Nowego Państwa Egipskiego ${ }^{20}$, podtrzymywane ono było

${ }^{16}$ Canones Hippolyti 21, thum. J. Szymańczak, w: Canones Patrum Graecorum, SCL 3, Kraków 2009, 191. Więcej w tej kwestii por. S. Barrett-Lennard, The Canons of Hippolythus and Christian Concern with Illness, JECS 13 (2005) 137-164.

${ }^{17}$ Cyt. za: W. Riedel, Die Kirchenrechtsquellen des Patriarchats Alexandrien, Leipzig 1900, 251-252, thum. własne.

${ }^{18}$ Cyt. za: tamże, s. 252, tłum. własne.

${ }^{19}$ Cyt. za: tamże, s. 253, tłum. własne.

${ }^{20}$ Por. E.L. Harris, Ancient Egyptian Divination and Magic, Boston 1999, 108; K.S. Kolta - D. Schwarzmann-Schafhauser, Die Heilkunde im Alten Ägypten, Stuttgart 2000, 138-139; C.R. Dil- 
przez starożytnych Greków ${ }^{21}$, a przykłady potwierdzające takowe przekonanie dostarczają także koptyjskie wczesnobizantyńskie teksty magiczne ${ }^{22}$. W cytowanych powyżej Kanonach Bazylego odnajdujemy również informację wskazującą na „właściwą porę” stosowania owych zabiegów leczniczych z wykorzystaniem oliwy. Była ona jednak zapewne inna od tej, jaką miał na myśli Chryzostom, opisując zwyczaj czerpania oliwy z kościelnej lampy, praktykowany przez antiocheńskich chrześcijan.

Z cytowanych powyżej kanonów Bazylego wynika, iż wykorzystywanie oliwy, której skuteczność potęgowana była wypowiadaniem przez pogańskich magów zaklęć, nadal było praktykowane u schyłku IV w. w Egipcie, a z ich usług korzystali także chrześcijanie. Jakby więc owej praktyki nie określać, to nie był to zwykły zabieg leczniczy i doskonale zdawali sobie z tego sprawę zarówno praktykujący go chrześcijanie, jak również duchowni bądź święci mężowie, którzy nacierali nią chorych odmawiając w czasie tej czynności modlitwę. Preferując zaś poddawanie się praktyce namaszczania oliwą w kościele lub też w martyrionie (w pobliżu relikwii męczennika), wyrażano przede wszystkim przekonanie, iż to świętość miejsca stanowi dodatkowy czynnik gwarantujący skuteczność zabiegu. Analogiczne przekonanie towarzyszyło również stosowaniu oliwy zaczerpniętej w kościele z wiecznej lampy.

Zestawione powyżej relacje obrazują stosowanie interesującej nas tu praktyki na obszarze Egiptu, Palestyny, Syrii (Antiochia oraz tereny wiejskie) oraz Bitynii. Postrzegane jako szczególnie skuteczne, musiały być one także stosowane przez chrześcijan w innych prowincjach rzymskiego Wschodu. Na pewno znane one były również na Zachodzie, o czym świadczą relacje Sulpicjusza Sewera $^{23}$ oraz Augustyna z Hippony ${ }^{24}$.

Jeśli w opisanych powyżej praktykach chodziłoby tylko o wykorzystanie naturalnych właściwości oliwy, wówczas nie starano by się pozyskać jej z kościelnej lampy, czy też otrzymać z rąk duchowieństwa. Nie interesowałby się tą kwestią także kościelny ustawodawca. W takim przypadku ograniczono by się do stosowania zwykłej oliwy spożywczej, bez odmawiania nad nią modlitwy. Ci zaś, których było na to stać, udawali się do lekarza, który chociażby na chorą gałkę oczną (jedna z najczęstszych dolegliwości we wschodnich pro-

laire, Egyptian Prosperity Magic. Spells and Recipes for Financial Empowerment, Woodbury 2011, 24- 28.

${ }^{21}$ Por. Ch. Ulf, Die Einreibung der griechichen Athleten mit Öl, „Stadion” 5 (1979) 220-238; D. Sansone, Greek Athletic and the Genesis of Sport, Berkeley - Los Angeles 1988, 96-97; R.B. Bottigheimer, Magic Tales and Fairy Tale Magic. From Ancient Egypt to the Italian Renaissance, New York 2014, 20.

${ }^{22}$ Por. W.H. Worrell, Coptic Magical and Medical Texts, „Orientalia” 4 (1935) 186-187; M.W. Meyer - R. Smith, Ancient Christian Magic: Coptic Texts of Ritual Power, Princeton 1999, 175.

${ }^{23}$ Por. A. Heinz, Die Krankensalbung in spätantiken Gallien. Das Zeugniss der Martinsschriften des Sulpicius Severus (um 400), ThZ 106 (1997) 271-287.

${ }^{24}$ Por. J. Zellinger, Augustinus und die Volksfrömmigkeit. Blicke in den frühchristlichen Alltag, München 1933, 58. 
wincjach Imperium) nałożyłby balsam lub też zalecił pacjentowi stosowanie sporządzonej przez siebie maści ${ }^{25}$.

Zestawione powyżej relacje (w tym przede wszystkim ówczesne kościelne teksty normatywne) nie dotyczą więc zwykłych zabiegów leczniczych. Wskazują one na przypisywanie cudownej, żeby nie powiedzieć - magicznej mocy uzdrawiania oliwie pozyskanej w szczególny sposób, a do tego jeszcze w świętym miejscu, w kościele bądź w martyrionie, i co do tego nie ma chyba żadnych wątpliwości. Mimo tak brzmiącego stwierdzenia daleki jednak jestem, by mówić o „magii chrześcijańskiej” w późnej starożytności ${ }^{26}$. Czegoś takiego nie było, zaś różnego rodzaju praktyki magiczne uprawiane wówczas przez chrześcijan są zupełnie czymś innym.

Bardziej więc $\mathrm{w}$ opisanych powyżej przypadkach mamy do czynienia $\mathrm{z}$ reliktem dawnych praktyk, przypisywaniem szczególnych właściwości leczniczych oliwie, nad którą poganie wypowiadali zaklęcia magiczne, a w interesującym nas okresie, w środowisku chrześcijan, odmawiano modlitwę wierząc, iż wzmocni ona skuteczność zabiegu. Nie jest to więc medycyna, a działanie silnie podparte wiarą, a w zasadzie przekonaniem, iż tylko w konkretny sposób pozyskana lub też w szczególny sposób zastosowana oliwa jest w stanie ulżyć pewnym dolegliwościom (dermatologicznym, gastrycznym), przywrócić mowę czy też uleczyć chromego.

Powyższe rozważania stanowią jedynie krótkie wprowadzenie do dyskusji nad wiarą $\mathrm{w}$ cudowne właściwości oliwy pozyskanej w szczególny sposób w kościele bądź w martyrionie. By właściwie ocenić opisane zjawisko należy na nie spojrzeć z punktu widzenia człowieka starożytności, dla którego praktyki magiczne stosowane w życiu codziennym były nie tylko czymś oczywistym, ale przede wszystkim skutecznym działaniem na rzecz ochrony przed wszelakim złem oraz utratą zdrowia. Analizując konkretne przypadki, chciałem zwrócić także uwagę na fakt, iż późnoantyczne chrześcijaństwo borykało się z wieloma przeciwnościami wynikającymi z różnorodności kulturowej wiernych, ich przywiązaniem do antycznej tradycji, również w sposobie okazywania pobożności. Dostrzegając w opisanym zjawisku elementy magii widzimy jednak, iż jest ono również potwierdzeniem religijności praktykujących je chrześcijan, którzy w taki sposób manifestowali przywiązanie do religii, w której upatrywali nadzieję na uzdrowienie.

${ }^{25}$ Por. Joannes Chrysostomus, In Matthaeum hom. 88, 3, PG 58, 779, thum. J. Krystyniacki, ŹMT 23, Kraków 2003, 513. Więcej w tej kwestii por. W. Ceran, Jan Chryzostom o leczeniu i lekarzach, Acta Universitatis Lodziensis. Folia Historica 48, Łódź 1993, 19.

${ }^{26}$ Innego zdania zdają się być M. Ożóg i H. Pietras (Praktyki magiczne w aktach synodalnychzarys problematyki, w: Zabobony, czary i magia w Kościele starożytnym, red. M. Ożóg - N. Widok, Opolska Biblioteka Teologiczna 138, Opole 2013, 97). 
SOME REMARKS ON THE QUASI-MEDICINAL USE OF OIL BY CHRISTIANS IN THE EARLY BYZANTINE PERIOD

(Summary)

Sources of the Early Byzantine Period describe Christian practices of using oil for medical purposes. These practices were not usual medical procedures. The sources describe the medical use of oil obtained from church lamps or given by clergymen or by holy men, whose prayers were believed to strengthened the "medical" properties of the oil. These practices were used by Christians in many provinces of the Eastern Roman Empire, including Egypt, Palestine, Syria and Bithynia.

Key words: ancient Christianity, pagan customs in everyday life of ancient Christians, ancient history, early Byzantium.

Slowa kluczowe: antyczne chrześcijaństwo, obyczaje pogańskie w życiu codziennym antycznych chrześcijan, historia starożytna, wczesne Bizancjum. 